\title{
Greening of education in modern society
}

\author{
Julia Isakova, and Maxim Pchelnikov ${ }^{*}$ \\ Don State Technical University, Law Faculty, Law of Crime and Criminalistics; 344000 \\ Rostov-on-Don, Russian Federation
}

\begin{abstract}
The necessity of transition to ecologically oriented civilization, conditionality of formation of system of knowledge in education education and culture is shown. The system of values of ecocentric orientation is offered. In the conditions of transitive modern society the complex of ecologically significant skills is formed at receiving education and is transformed into internal beliefs of the individual. It is argued that the modern reality requires immediate initiation and development of ecological education of youth at all stages and levels of education: the state of the environment can not wait for full formation of generations, which is subject-oriented environmental education in early childhood, and does not allow time for long-term experiments.
\end{abstract}

\section{Introduction}

The intensification of environmental and anthropogenic challenges in transitive society suggests the ever-increasing importance of environmental upbringing, education and outreach for society. This trifecta is meant to be a framework for developing of citizen awareness of environment state, environmental safety factors, causes and consequences of detrimental influence of a man on nature. According to the rule indicated in Article 42 of the supreme legislative decree of the Russian Federation - the country's Constitution [1], approved in a referendum in 1993, the right to a sound, satisfactory and healthy environment is one of the fundamental and comprehensive human and citizens rights, influencing a basic life activity associated with maintenance of normal environmental, economic and esthetic living conditions.

\section{Results and discussion}

Escalation of global environmental problems on the cusp of XX-XXI centuries has demonstrated clearly to the whole international community the current necessity of reevaluation of the entire system of environmental education, upbringing and outreach. In the era of a transitive society consideration must be given not only to business anthropogenic activities, but also to social needs in natural resources management. We are

\footnotetext{
* Corresponding author: pchelnikov-m@mail.ru
} 
in full agreement with Paul Shrivastava concerning the necessity of this issue to be reflected in advanced educational programs [2].

The beginning of the modern century was marked by the joint resolution of environmental agencies leaders of Central Asia, North America and Europe at the V Conference "Environment for Europe" (2003, Kiev) on development of regional strategies of educational programs for sustainable development. This important pact adoption was preceded by the tremendous preliminary work of committees and groups under the joint chairmanship of Russia and Sweden. Thus Russia was able to participate actively in this strategy development, offering to use the elements of national environmental policy in education on a worldwide basis [3].

We suppose that now we can say confidently that the concept of environmental education for sustainable development has been formed due to the advanced experience of Russia and a number of other concerned countries, especially North Europe, in the field of environmental education. Due to the given concept the very idea of multidisciplinary and integrated approach in education is displaced to the sphere of interest of sustainable social and environmental development. What is more, the initiation of education greening refers specifically to the transitional period of XX-XXI centuries. At the same time the researches report that lack of attention of a number of countries to the issues of environmental education, upbringing and outreach is a hindrance to orientation of educational processes for sustainable development, which also includes either social and economic aspects [4].

Please note that in present day conditions of transitive society such an environmental policy, and the sphere of education as well, which is focused on environment protection and preservation of environmentally sound ecological conditions of living organisms, a human including, assumes paramount significance [5].

We can't fail to agree with a reasonable demand of the international ecology movement to regard a reform in the field of education greening at all levels as the basis of current educational system improvement within the context of actual environmental degradation [6]. It is also worth noting that currently the environmental education in the Russian Federation, both in government, municipal and private facilities, relies primarily on the valid national standards in the field of education.

The school level of environmental education implementation is carried out both in the form of class-and-lesson system and extracurricular activity within the boundaries of principal educational program of the organization, with the individual program preparation. The college level of education greening (and nobody argues with that) is also among priority orientations of actual environmental policy in the sphere of education (the Federal Law

«On the Education in the Russian Federation») [7].

The national regulations for ecological legal relations, including education greening, were only recently adopted. So, the adoption in 2002 of the Federal Law "On Environmental Protection" has made it possible to enshrine on the legislative level the norms of ecological culture development, which suggest generality and complexity of modern education greening, managers and officials training in the field of ecological safety and nature protection, and also the mandatory teaching of ecological principles in educational institutions, promotion of ecological awareness (Chapter XIII of the Federal Law “On Environmental Protection” dt. 10.01.2002 №Ф3) [8].

A society, which is in a state of selection of a model of interaction with nature will always look for the best ways of environmental policy-making. The current community demands are primarily related to the manifestations of complex (interdisciplinary) character of environmental global problematic, that apparently implies changes in education policy by means of education humanization and greening. This process involves a anthropocentric values paradigm change by means of the ecocentered personal culture development. 
The concept of ecocentrism, which has the educational sector origin and considers the world around and nature as the independent system of values, is no longer only a part of training courses. The current concept of ecocentrism is manifested particularly in strong position on life, readiness for socially important and environmentally conscious actions, also those that impose self-discipline and self-restriction, and are related to responsibility for decision making and actions not only to currently living, but also to future generations [9].

In addition to education, upbringing is also an important component of modern society greening. The primary aim of environmental upbringing is moral order organization in the system of universal human and ecological values. The ecological component of present day upbringing in educational organizations is seen as influence and teaching of students, typically by personal example of a teacher, with purpose of sustainable ecological and environment oriented thinking forming, creating of modern moral, juridical, economical and aesthetic views on environment, determination of place and role of an individual in environmental protection ensuring. It is acknowledged that environmental culture and environmentally friendly consciousness of each member of a society is a necessary condition of sustainable society development [10].

Whereas the activities in the field of development and mainstreaming of ecological and conservation values have been carried out in the world for more than a half of the century already, the feature of ecological culture is its nonsimultaneous development, with a possibility of duration over the course of decades. It should be realized that this precludes achievement of relatively meaningful and immediate results. But the ongoing progress in this direction can put a society together over environmental priorities and give a crucial change in multigenerational thinking, that ultimately can form a "new environmental thinking" based on environmental education, upbringing and outreach. Raising of general environmental culture, careful attitude to the world around in transitive society could become a necessary condition for sustainable development of modern society and its ecologization.

There is no need to separate the environmental education as an independent part, unrelated to other values of modern culture of education. Environmental education as a primary element of modern environmental culture should be perceived as unreplaceable one, and first of all as socially oriented adaptation of an individual to rapidly changing socio-natural environments. Having passed a significant stage of biological evolution the humanity, as the subject of influence on nature and the object of changes, can not rely on the natural course of planetary events. To survive in this changed natural-anthropogenic world it is necessary to apply mechanisms of social integration, combinations of social and natural forms, with development of different ecological culture.

Rules of law and cultural practices, with their interaction with one another, have always played a pivotal role in the development social medium in human society. We believe that it is environmental culture definitely, in its modern meaning, which establishes the necessary rules in society, its norms and visions of human behavior pattern in these changed social and natural conditions. According to the researchers reports the vector of environmental consciousness and policy development is shifting from "Don't expect mercy from nature" to the establishment of global "green" control [11].

In an attempt to build ideological boundaries as a response for challenges of modernity the today's Russia finds new opportunities in the greening of education. The current environmental education increasingly focuses on the harmonization of youth development, social advancement, and the entire country development in a patriotic way, based on thoughtful interaction with nature and the environment.

In our opinion the chosen course is adequate, but with the necessity of some adjustment. The ideology of ecological education in Russia, which includes environmentally friendly 
upbringing, should be the ideology of preserving the native country with its rich natural and cultural diversity. One of the ways of overcoming the current ecological crisis is emerging role of environmental culture. Not only the spiritual growth of a society should be considered the major indicator of the level of society culture, but also morality of its population, the extent of environmental principles introduction in people's activity related to preservation and reproduction of natural wealth.

Ecological culture plays a facilitating role in positive alteration of modern consciousness, the formation of the ecological segment of public spirit, ecological world view and environmental imperatives, with not only developing into beliefs, but also becoming a style of our life. Our understanding is that the developed type of the efficient environmental world consciousness is the very factor that should establish the behavior and attitude of individuals to the surrounding world, the nature of their native country, and form a sense of patriotism.

\section{Conclusions}

Environmental culture, like every other type of modern culture, it is not only and not so much a body of knowledge, as it is also a set of skills that develops into moral certainty. It is very important to realize the acquired knowledge in strongly needed socially significant initiatives, youth trends and movements, been followed up by practical deeds. without reducing emphasis on environmental education and upbringing.

Our understanding is that the present day reality imposes the introduction and development of the environmental education of youth at all educational stages and levels (Higher education - undergraduate and graduate programs): the environment condition is unable to wait for complete formation of generations, that are the object of oriented environmental upbringing from early childhood, and does not allow time for long-term experiments.

The principal condition of the activities in this field is participation and interaction between environmental professionals, teachers, scientists, administrators and managers, and wide ecological public, who inculcate qualities of professional and high moral personality in higher school students through the environmental education and upbringing.

\section{References}

1. Konstitutsiya Rossiiskoi Federatsii (1993)

2. P. Shrivastava Journal of Management Inquiry. 3(3). 235-243 (1994)

3. M.V. Pchelnikov, Problems and Perspectives. 104-107 (2013)

4. Ja. Sureda, A.M. Calvo, The Environmentalist. 21(4), 287-296 (2001)

5. M.V. Pchel'nikov, Aktual'nye problemy sovremennosti: nauka i obshchestvo. 2(7), 42 $44(2015)$

6. A. Isakova, International Multidisciplinary Scientific GeoConference Surveying Geology and Mining Ecology Management, 115-122 (2018)

7. Federal'nyi zakon "Ob obrazovanii v Rossiiskoi Federatsii" (2012)

8. Federal'nyi zakon «Ob okhrane okruzhayushchei sredy» (2002)

9. S.I. Kuzina, Vestnik Severo-Kavkazskogo gumanitarnogo instituta. 2(6), 324-331 (2013)

10. Yu.A. Kuz'menko, M.V. Pchel'nikov, Gumanizatsiya vysshego professional'nogo obrazovaniya: tseli, soderzhanie, sposoby osushchestvleniya (Rostov-na-Donu, 2015)

11. W.Ch. Mathisen, Gree utopianism and greening of science and higher education. Organization \& Environment. 19(10), 110-125 (2006) 